\title{
HLA Class II Histocompatibility Antigen, DRB1-4 Beta Chain Protein
}

National Cancer Institute

\section{Source}

National Cancer Institute. HLA Class // Histocompatibility Antigen, DRB1-4 Beta Chain

Protein. NCI Thesaurus. Code C62757.

HLA class II histocompatibility antigen, DRB1-4 beta chain protein (266 aa, $30 \mathrm{kDa})$ is encoded by the human HLA-DRB1 gene. This protein is involved in both antigen presentation to regulatory $T$ cells and in the immune response. The antigen is frequently typed for bone marrow and kidney transplantation procedures. 